\title{
Antibacterial Properties of Whey Protein Coating and Mentha aquatica L. Essential Oil on Coliform Bacteria in Iranian White Cheese
}

\author{
Sajedeh Rezaiee ${ }^{1}$, Fatemeh Ardestani $^{2} *$, Morteza Khoshvaght ${ }^{1}$ \\ 1- Department of Chemical Engineering, Shahrood Branch, Islamic Azad University, Shahrood, Iran \\ 2- Department of Chemical Engineering, Qaemshahr Branch, Islamic Azad University, Qaemshahr, Iran
}

\section{A B S T R A C T}

Background and Objectives: In this study, antibacterial effects of whey protein coating with Mentha aquatica $L$. essential oil on Escherichia coli, Enterobacter and Klebsiella pneumoniae in Iranian white cheese were investigated.

Materials and Methods: Mentha aquatica L. essential oil was extracted using Clevenger apparatus. Mentha aquatica L. essential oil was added to each whey protein coating solution at $0.5,1$ and $1.5 \%$ concentrations. Whey protein treatment included cheese, bacteria and whey protein with no Mentha aquatica L. essential oil. Control treatment only included cheese and bacteria with no Mentha aquatica L. essential oil and whey protein. Minimal inhibitory concentration and minimal bactericidal concentration were assessed for the bacterial species. Antibacterial properties of the designed active coating system against Escherichia coli, Enterobacter and Klebsiella pneumoniae were assessed using direct cell counting and disk diffusion methods.

Results: Mentha aquatica L. essential oil at $1.5 \%$ concentration at the end of Day 15 of storage at $4{ }^{\circ} \mathrm{C}$ inhibited growth of Escherichia coli, Enterobacter and Klebsiella pneumoniae up to 100, 64 and 18\%, respectively. To achieve the highest growth inhibition of Escherichia coli, Enterobacter and Klebsiella pneumoniae, 1.5, 1 and 1\% of the essential oil were used to preserve organoleptic properties of the cheese.

Conclusions: Use of whey protein coating with $1.5 \%$ essential oil included no adverse effects on organoleptic, sensory and appearance characteristics of the cheese. Whey protein coating with Mentha aquatica L. essential oil inhibited growths of Escherichia coli completely and Enterobacter partially in Iranian white cheese.

Keywords: Biopolymer coating, Enterobacter, Escherichia coli, Essential oils, Food protection, Dairy products, Klebsiella pneumonia

\section{Introduction}

Based on the increased world population and needs to conserve resources for the future generations, researchers have searched for novel solutions of food and food packaging, including use of antibacterial packaging technology. Recent spread of microbial contamination has fascinated researchers to look for innovative ways to inhibit microbial growth in foods without compromising food quality, freshness and safety. One solution is to use active packaging to provide margins of safety and quality (1). Active packaging is generally a type of packaging. In addition to include basic properties of conventional packaging such as gases and water vapor and mechanical stress tolerance, active packaging preserves and enhances safety, shelf-life and sensory properties of the foods. Furthermore, active packaging enables new functions such as antibacterial and antioxidant properties of the packaging materials and absorption of oxygen, moisture and ethylene by the packaging absorbent materials as well as controlled releases of flavored and ethanol substances into the foods. In this type of packaging, spread of antibacterial substances from the polymeric matrices to the surfaces of foods is carried out slowly over a specified period of time. Therefore, a relatively high concentration of the antibacterial substances is always present in the product surface, resulting in increases in shelf-life of the products (2).

Effective compounds extracted from various plant organs include anti-pain, anti-inflammatory, insecticidal, antimicrobial, antioxidant and other therapeutic properties. These compounds are collected from various parts of plants, including leaves, stems, roots, flowers, leachates 
and gums (3). Use of Mentha essential oil and whey protein coating showed more antibacterial effects on various bacteria, compared to that use of garlic and rosemary did (4). Antibacterial activity of whey protein coating and 5\% Mentha essential oil was investigated in beef packaging (5) and traditional lighvan cheese (6) with the highest inhibitory effects on Escherichia coli, Pseudomonas and Listeria monocytogenes. Moreover, Mentha essential oil associated with chitosan coating was an effective antibacterial packaging system against $E$. coli, Staphylococcus aureus and L. monocytogenes in Iranian white cheese. Furthermore, Teucrium polium essential oil included similar effects against E.coli O157:H7 in Kishk (7, 8). Active packaging prepared using low-density polyethylene films loaded by titanium dioxide and zinc oxide nanoparticles showed significant antibacterial effects on E. coli (9) and S. aureus (10). Other plant extracts such as Zataria multiflora, Laurus nobilis and Chamaemelum nobile essential oils demonstrated good antibacterial properties against pathogenic $E$. coli $(11,12)$.

Biopolymers include advantages such as biodegradability, renewability and low costs to conventional packaging materials from synthetic polymers and petroleum derivatives. Protein coatings include good capabilities such as ductility, elasticity and oxygen permeability but are highly permeable to water and moisture. These coating are good to prevent moisture from penetrating coatings of fats; however, their resistance to oxygen passage is poor (13). Mechanical properties of these materials are poor. Addition of microbial transglutaminase to whey protein-based coatings improved their physicochemical properties, including water vapor permeability, tensile strength, elongation and solubility in water $(14,15)$. Coliforms are a group of Gram-negative bacteria, commonly referred to as indicators of food quality and water hygiene. These bacteria are morphologically bacilli-shaped and actually immobilized that ferment lactose when exposed to acid and gas at 35-37 ${ }^{\circ} \mathrm{C}$. Coliforms are detected in aquatic, soil and vegetation environments. Moreover, these bacteria exist in feces of warm-blooded animals and their natural habitats include human and warm-blooded animal gastrointestinal tract (GIT) (16). Most E. coli strains are harmless; however, serotypes such as O157: H7 cause food poisoning and diarrhea and act as opportunistic pathogens, causing infections such as blood poisoning, urinary tract (UT) infections, pulmonary infections in immunocompromised people and neonatal brain infections (17). Klebsiella causes complicated UT infections, intra-abdominal infections, cellulitis, surgical wound infections and meningitis linked to brain and nerve surgeries (18). Enterobacter cloacae and E. aerogenes are responsible for most of the infections caused by Enterobacter spp., producing clinical syndromes similar to those caused by Klebsiella spp. These species play important roles in causing hospital infections (19). The aim of the current study was to assess antibacterial effects of whey protein coating containing $M$. aquatica $L$. essential oil against pathogenic coliforms, E. coli, Enterobacter and $K$. pneumoniae in Iranian white cheese.

\section{Materials and Methods}

\section{Materials}

Lyophilized E. coli PTCC1330 (O157:H7), Enterobacter PTCC1291 and K. pneumoniae PTCC1290 from the Persian Type Culture Collection (PTCC) were provided by the Iranian Research Organization for Science and Technology, Iran. Lactococcus lactis subsp. diacetylactis and L. lactis subsp. cremoris (Chr. Hansen R 704) and rennet were purchased from Chr. Hansen (Christian Hansen, Denmark). The M. aquatica L. fresh leaves were collected from Mazandaran Province, Iran. Blood agar, nutrient agar and Mueller-Hinton agar were purchased from Merck, Germany. MacConkey agar and plate count agar were provided by Sigma-Aldrich, USA. Whey protein isolate powder was purchased from Alra Food Ingredient, Denmark. Food grade glycerol was provided by Merck, Germany. All other chemicals were purchased from Iranian reliable manufacturers.

\section{Mentha aquatica L. essential oil}

The M. aquatica L. essential oil was prepared using Clevenger apparatus and water distillation method. The $M$. aquatica $\mathrm{L}$. fresh leaves were dried at $55{ }^{\circ} \mathrm{C}$ for $75 \mathrm{~min}$ using vacuum oven and were then powdered. Essential oil extraction process continued until the essential oil vapors were detected in cooling section of the apparatus and volume of the achieved essential oil was constant with no increases. Due to the organic nature of essential oils, a nonpolar solvent of normal hexane $(1 \mathrm{ml})$ was used to increase the essential oil collection. Collected aromatic water in the pipe contained a very small quantity of the essential oil. Then, essential oil was separated from the aromatic water. At each stage of the extraction process, $150 \mathrm{~g}$ of dried leaves with $700 \mathrm{ml}$ distilled water (DW) were poured into a glass balloon and extraction was carried out at $100{ }^{\circ} \mathrm{C}$ for $150 \mathrm{~min}$. Essential oil was dehydrated with dry sodium sulfate and stored at $4{ }^{\circ} \mathrm{C}$ inside dark glass containers with aluminum cover. In general, nearly $4 \mathrm{~g}$ of the essential oil was achieved from $150 \mathrm{~g}$ of powdered mint leaves. The essential oil extraction was carried out for several times and nearly $35 \mathrm{~g}$ of the essential oil were prepared $(9,10)$.

\section{Whey protein solution}

In this study, commercial whey protein powder was used. To prepare whey protein coating solution, $5 \mathrm{~g}$ of whey protein were dissolved in $100 \mathrm{ml}$ of DW and agitated at $100 \mathrm{rpm}$ for $3 \mathrm{~h}$ at room temperature using magnetic stirrer (IKA pH Basic 2, Germany). Then, $2 \mathrm{~g}$ of glycerol were added to the solution as plasticizer, mixed for $10 \mathrm{~min}$ 
using magnetic stirrer and centrifuged to remove impurities. Coating solution, including $5 \%$ of whey protein and $2 \%$ of glycerol, was heated at $80{ }^{\circ} \mathrm{C}$ for 30 min with agitation using water bath. Heating was carried out to form intermolecular disulfide bonds. The optimum coherence and flexibility of the polymeric coating depended on the formation of covalent and non-covalent cross-links. Whey protein coating was then cooled in an ice water bath to prevent excessive denaturation of the proteins until they reached $45{ }^{\circ} \mathrm{C}(20)$. Then, $M$. aquatica $\mathrm{L}$. essential oil was added at $0.5,1$ and $1.5 \%$ concentrations to the whey protein coating solutions and mixed at $100 \mathrm{rpm}$ for $30 \mathrm{~min}$ using magnetic stirrer. Control solution was prepared using similar protocol with no M. aquatica L. essential oil.

\section{Recovering of the bacteria and preparation of fresh cultures}

To recover initial suspensions from E. coli PTCC1330 (O157:H7), Enterobacter PTCC1291 and K. pneumoniae PTCC1290, contents of the vials were separately dissolved in three test tubes, containing $5 \mathrm{ml}$ of sterile DW. Suspensions were cultivated immediately on slants in oblique directions as well as on a few Petri dishes of MacConkey agar, blood agar and nutrient agar for E. coli, Enterobacter and $K$. pneumoniae, respectively. Then, 0.1 $\mathrm{ml}$ of diluted bacterial suspensions petri dishes was added to the solid culture media. Petri dishes were incubated at 37 ${ }^{\circ} \mathrm{C}$ for $24 \mathrm{~h}$ until bacterial colonies appeared. These plates were then used to prepare bacterial suspensions (12). Counting of the colonies was carried out using direct cell counting method.

\section{Preparation of cheese}

To ensure that milk was not contaminated with E. coli, Enterobacter and $K$. pneumoniae, samples were assessed before cheese making process. Briefly, five milk samples (each nearly $1 \mathrm{l}$ ) were pasteurized at $72{ }^{\circ} \mathrm{C}$ for $10 \mathrm{~min}$ and then cooled down to $35{ }^{\circ} \mathrm{C}$. Microbial assessment was carried out to ensure no existence of E. coli, Enterobacter and $K$. pneumoniae in pasteurized milk. Nearly $10^{5}$ cell ml ${ }^{1}$ of each E. coli, Enterobacter and K. pneumoniae were inoculated in pasteurized milk. Then, $1 \% \mathrm{w} / \mathrm{v}$ of starter, including Diacetylactis and L. lactis subsp. Cremoris (Chr. Hansen R 704; Christian Hansen, Horsholm, Denmark) was added to the milk samples. After $30 \mathrm{~min}, 0.2 \% \mathrm{w} / \mathrm{v}$ of calcium chloride dissolved in $20 \mathrm{ml}$ of sterile DW at $40{ }^{\circ} \mathrm{C}$ was uniformly added to the milk. After $24 \mathrm{~h}$ when $\mathrm{pH}$ reached to 5-5.5, 0.005\% w/v rennet (Christian Hansen, Horsholm, Denmark) was added to the milk and routine cheese producing steps were carried out (8).

\section{Minimal inhibitory concentration and minimal bactericidal concentration}

To assess minimal inhibitory concentration (MIC) and minimal bactericidal concentration (MBC), standard microdilution method (NCCLS) was used (21). Briefly, 10 test tubes containing $10 \mathrm{ml}$ of sterile nutrient broth and various dosages of $M$. aquatica $\mathrm{L}$. essential oil of $0-5 \%$ were used for each bacterial strain. Inhibitory effects of ten various dosages of $0,0.05,0.1,0.2,0.5,1,2,3,4$ and $5 \%$ $\mathrm{v} / \mathrm{v}$ M. aquatica L. essential oil against each bacterial strain were assessed. Samples were incubated at $37{ }^{\circ} \mathrm{C}$ for $24 \mathrm{~h}$ and the essential oil concentration of the plates, including the most and the least bacterial colonies, were considered as MIC and MBC, respectively.

\section{Coating the cheese samples with whey protein solution}

First, small cubic pieces of cheese, weighing approximately $30 \mathrm{~g}$, were prepared using sterile sharp blades. Then, whey protein coating on the samples was carried out through submerging samples in whey protein solution using two 5-min steps. Pieces of cheese were incubated at $10{ }^{\circ} \mathrm{C}$ for $5 \mathrm{~h}$ until the coating formed completely. Then, samples were transferred to the refrigerator, stored at $4{ }^{\circ} \mathrm{C}$ for 15 days and assessed every five days for the growth of $E$. coli, Enterobacter and $K$. pneumoniae. Samples were as follows:

1) $0.5 \%$ treatment contained cheese, bacteria and whey protein coating with a concentration of $0.5 \% \mathrm{M}$. aquatica L. essential oil.

2) $1 \%$ treatment contained cheese, bacteria and whey protein coating with a concentration of $1 \%$ M. aquatica $\mathrm{L}$. essential oil.

3) $1.5 \%$ treatment contained cheese, bacteria and whey protein coating with $1.5 \%$ concentration of $M$. aquatica $\mathrm{L}$. essential oil.

4) Whey protein treatment contained cheese, bacteria and whey protein coating with no $M$. aquatica $\mathrm{L}$. essential oil.

5) Control treatment contained cheese, bacteria with no $M$. aquatica L. essential oil and whey protein coating.

\section{Antibacterial survey}

Antibacterial effects of whey protein coating and $M$. aquatica L. essential oil against E. coli, Enterobacter and $K$. pneumoniae in Iranian white cheese were assessed using two methods of direct cell counting and disk diffusion methods. In former method, surface cultivation was used to assess the microbial count of E. coli. A sample was removed from each treatment and assessed separately. For each sample, $5 \mathrm{~g}$ of cheese were dissolved in $45 \mathrm{ml}$ of sterile peptone water completely homogenized. Dilutions of $10^{-4}$ and $10^{-3}$ were used. In general, $0.1 \mathrm{ml}$ of the sample was removed with a sterile pipette and spread on a plate surface containing MacConkey agar. After $48 \mathrm{~h}$ of incubation at $37^{\circ} \mathrm{C}$, colonies were counted. This was carried out for each treatment separately at consecutive times (every five days for 15 days). For Enterobacter and K. pneumoniae, similar protocols were used using blood agar and nutrient agar, respectively. 
In the latter method, essential oil was diluted with dimethyl sulfoxide to prepare 50, 100 and $150 \mathrm{mg} \mathrm{ml}^{-1}$ (equivalent to $0.5,1$ and $1.5 \%$ ) concentrations of $M$. aquatica L. essential oil. Then, $10 \mu \mathrm{l}$ of each solution were poured onto 6-mm blank disks for $3 \mathrm{~min}$. Bacteria were transferred to Mueller-Hinton broth (Merck, Germany) and incubated at $30{ }^{\circ} \mathrm{C}$ for $24 \mathrm{~h}$. Bacterial sources were prepared through culturing incubated Mueller-Hinton broth on Mueller-Hinton agar plates (for using) and slants (for storing). Suspensions of E. coli, Enterobacter and $K$. pneumoniae in sterile saline were prepared using McFarland 0.5 Standard solution of $1.5 \times 10^{8}$ bacterial units per $\mathrm{ml}$ (22). Then, a uniform culture was carried out using $100 \mu \mathrm{l}$ of the prepared suspension on the surface of Mueller-Hinton agar media. Antibacterial assessment was carried out at $37{ }^{\circ} \mathrm{C}$ for $24 \mathrm{~h}$ using three discs containing three concentrations of essential oil $(0.5,1$ and $1.5 \%$, respectively) as well as one disc as negative control. After incubation, inhibition zone diameters were measured and recorded. Discs containing methyl sulfoxide with no essential oil were used as negative controls (23).

\section{Organoleptic assessment}

First, small samples of cheese (nearly $10 \mathrm{~g}$ ) were prepared. Samples were impregnated with whey protein coating and $1.5 \%$ of $M$. aquatica L. essential oil based on the highlighted method in previous sections. A group of 40 students were selected to carry out the organoleptic assessment. Each student was given various cheese samples separately and then asked about the cheese taste, odor, appearance and color.

\section{Results}

\section{Minimal inhibitory concentration and minimal bactericidal concentration}

Based on the turbidity records and bacterial cell counting methods, the essential oil doses of 0.2 and $2 \%$ were considered as MIC and MBC for E. coli, respectively. For Enterobacter, similar findings were recorded. The MIC and MBC for Enterobacter were reported as 0.5 and $2 \%$, respectively. For $K$. pneumoniae, concentrations of 1 and $2 \% \mathrm{v} / \mathrm{v} M$. aquatica $\mathrm{L}$. essential oil were reported as MIC and MBC, respectively.

\section{Escherichia coli growth inhibition}

In this study, number of live bacteria in each treatment was compared to the number of bacteria in control sample. To assess decreases in live bacterial number in treatment of $1 \%$ essential oil after 10 days of storage, number of live bacteria in this treatment was compared to the number of live bacteria in control sample on Day 1. Similarly, all samples and controls were compared to control sample on Day 1. Number of live E. coli in control on Day 1 was 5.6 $\times 10^{5} \mathrm{CFU} / \mathrm{g}$. After 5 days of storage at $4^{\circ} \mathrm{C}$, number of $E$. coli per gram of cheese sample decreased as $23.83,34.75$ and $41 \%$ and respectively reached $4.25 \times 10^{5}, 3.64 \times 10^{5}$ and $3.30 \times 10^{5} \mathrm{CFU} / \mathrm{g}$ in treatments of $0.5,1$ and $1.5 \%$ essential oil, compared to control. On Day 10 of storage at $4{ }^{\circ} \mathrm{C}$, decreases of $47.14,61.1$ and $83 \%$ were recorded for the treatments of $0.5,1$ and $1.5 \%$ essential oil, respectively. Number of $E$. coli cells respectively reached $2.96 \times 10^{5}$, $2.18 \times 10^{5}$ and $0.95 \times 10^{5} \mathrm{CFU} / \mathrm{g}$ in treatments of $0.5,1$ and $1.5 \%$ essential oil. After 15 days of storage at $4{ }^{\circ} \mathrm{C}$, number of $E$. coli per gram of cheese sample decreased as 59.1, 75 and $98 \%$ and respectively reached $2.29 \times 10^{5}, 1.4 \times 10^{5}$ and $0.11 \times 10^{5} \mathrm{CFU} / \mathrm{g}$ in treatments of $0.5,1$ and $1.5 \%$ essential oil, compared to control (Fig. 1). The initial E. coli population in control was $5.65 \times 10^{5} \mathrm{CFU} / \mathrm{g}$, which increased to $5.88 \times 10^{5} \mathrm{CFU} / \mathrm{g}$ after 5 days. At the end of Day 10, number of $E$. coli in control reached $5.15 \times 10^{5}$ $\mathrm{CFU} / \mathrm{g}$ and decreased to $4.82 \times 10^{5} \mathrm{CFU} / \mathrm{g}$ at the end of the storage time (Day 15), decreasing of almost $14 \%$ compared to Day 1 (Fig. 1). Figure 1 shows the inhibitory growth rate of E. coli in each treatment at various time intervals, compared to control as well as antibacterial properties of whey protein coating and $M$. aquatica L. essential oil against E. coli PTCC1330 (O157:H7).

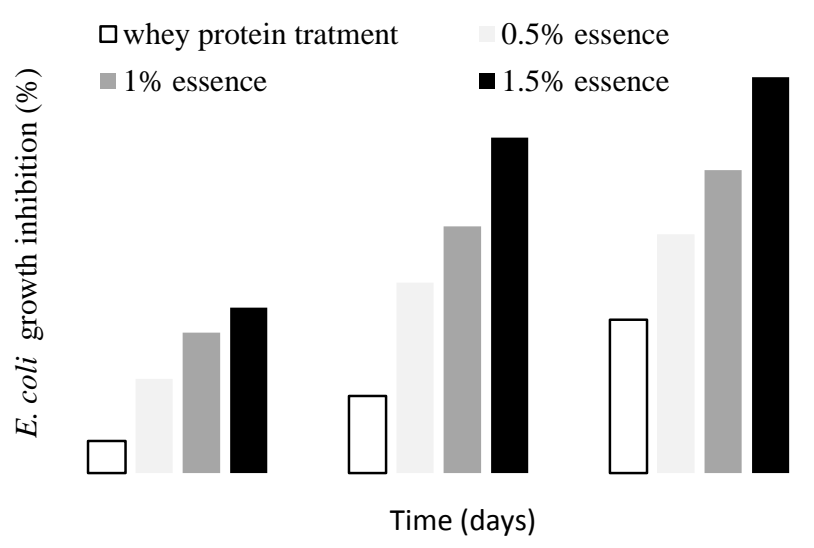

Figure 1. Escherichia. coli PTCC1330 (O157:H7) growth inhibition in Iranian white cheese using various doses of Mentha aquatica L. essential oil and whey protein coating within 15 days of storage at $4{ }^{\circ} \mathrm{C}$

\section{Enterobacter growth inhibition}

Number of the live bacteria in each treatment in each time interval was compared to the number of Enterobacter in control on Day 1. Similarly, all samples and controls were compared to control on Day 1. The approximate number of live Enterobacter on Day 1 was $6.2 \times 10^{5}$ $\mathrm{CFU} / \mathrm{g}$. After 5 days of storage at $4{ }^{\circ} \mathrm{C}$, number of Enterobacter decreased as 15, 18.06 and $23.55 \%$ and respectively reached $5.27 \times 10^{5}, 5.08 \times 10^{5}$ and $4.74 \times 10^{5}$ $\mathrm{CFU} / \mathrm{g}$ in treatments of $0.5,1$ and $1.5 \%$ essential oil, compared to control. On Day 10 of storage at $4{ }^{\circ} \mathrm{C}$, decreases of $42.26,59.2$ and $62.1 \%$ were recorded for the treatments of $0.5,1$ and $1.5 \%$ essential oil, respectively. 
Number of Enterobacter cells in treatments of 0.5, 1 and $1.5 \%$ essential oil reached $3.58 \times 10^{5}, 2.53 \times 10^{5}$ and 2.35 $\times 10^{5} \mathrm{CFU} / \mathrm{g}$, respectively. After 15 days of storage at $4{ }^{\circ} \mathrm{C}$, number of Enterobacter per gram of cheese sample decreased as $44,61.3$ and $64 \%$ and respectively reached $3.47 \times 10^{5}, 2.4 \times 10^{5}$ and $2.23 \times 10^{5} \mathrm{CFU} / \mathrm{g}$ in treatments of $0.5,1$ and $1.5 \%$ essential oil, compared to control (Fig. 2). For whey protein treatment, number of Enterobacter cells reached $5.86 \times 10^{5} \mathrm{CFU} / \mathrm{g}$ and recorded a $5.48 \%$ decrease after 5 days of storage at $4{ }^{\circ} \mathrm{C}$, compared to control. On Day 10, the mean number of Enterobacter in whey protein treatments decreased by $13 \%$, compared to control and the number of live bacteria reached $5.39 \times 10^{5} \mathrm{CFU} / \mathrm{g}$. This reached $4.28 \times 10^{5} \mathrm{CFU} / \mathrm{g}$ on Day 15 , which showed a decrease of $31 \%$ (Fig. 2). The initial live cells of Enterobacter in control included $6.2 \times 10^{5} \mathrm{CFU} / \mathrm{g}$, which increased to $6.68 \times 10^{5} \mathrm{CFU} / \mathrm{g}$ after five days. However, the initial live cells of Enterobacter decreased to $5.87 \times 10^{5}$ $\mathrm{CFU} / \mathrm{g}$ at Day 10 and $5.64 \times 10^{5} \mathrm{CFU} / \mathrm{g}$ at the end of the storage time (Day 15) with a decrease of almost $9 \%$, compared to Day 1 (Fig. 2). Figure 2 represents the antibacterial effects of whey protein coating and $M$. aquatica L. essential oil against Enterobacter PTCC1291 in various treatments and time.

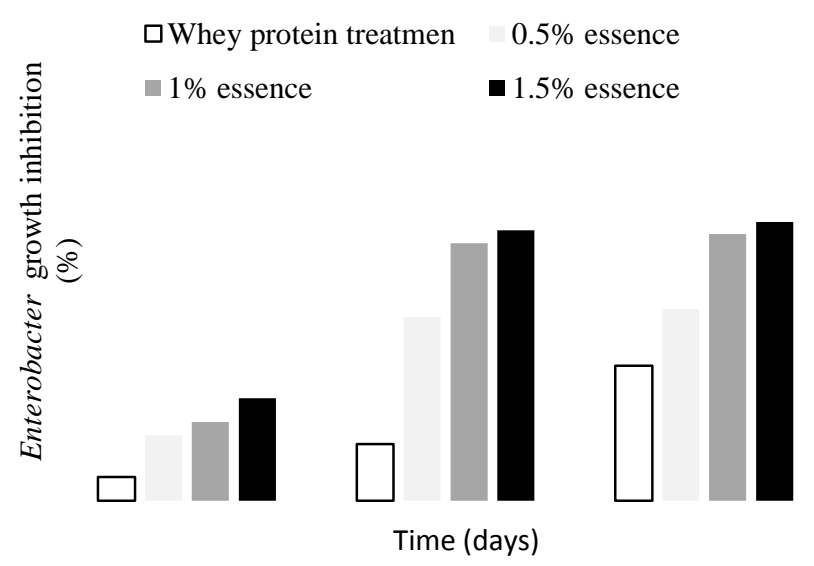

Figure 2. Enterobacter PTCC1291 growth inhibition in Iranian white cheese using various doses of Mentha aquatica $\mathrm{L}$. essential oil and whey protein coating within 15 days of storage at $4{ }^{\circ} \mathrm{C}$

\section{Klebsiella pneumoniae growth inhibition}

The initial number of live bacteria of K. pneumoniae in control on Day 1 was $4.78 \times 10^{5} \mathrm{CFU} / \mathrm{g}$, which increased to $5.26 \times 10^{5} \mathrm{CFU} / \mathrm{g}$ after five days. However, this decreased to $4.42 \times 10^{5} \mathrm{CFU} / \mathrm{g}$ on Day 10 and $4.32 \times 10^{5} \mathrm{CFU} / \mathrm{g}$ at the end of the storage time (Day 15), a decrease of almost 9.6\% compared to Day 1 (Fig. 3). The reason was exactly similar to that previously stated for $E$. coli and Enterobacter. Figure 3 shows the antibacterial properties of various doses of $M$. aquatica L. essential oil with whey protein coating against $K$. pneumoniae PTCC1290 within 15 days of storage at $4{ }^{\circ} \mathrm{C}$.

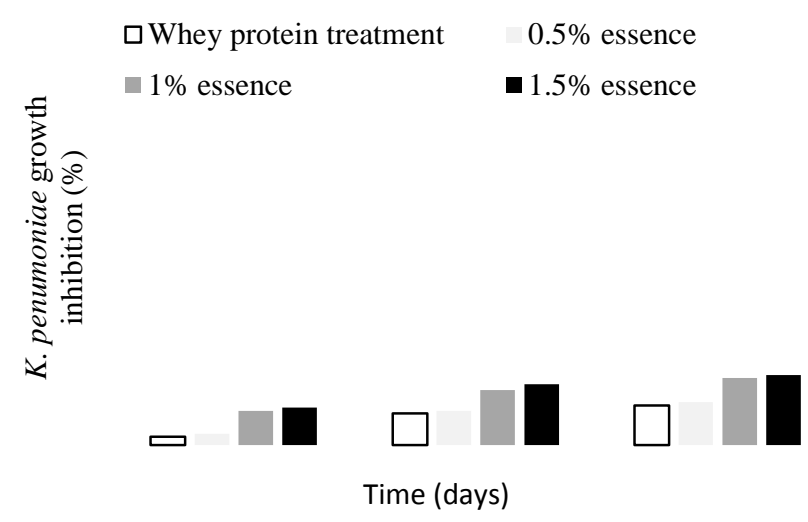

Figure 3. Klebsiella pneumoniae PTCC1290 growth inhibition in Iranian white cheese using various doses of Mentha aquatica L. essential oil and whey protein coating within 15 days of storage at $4{ }^{\circ} \mathrm{C}$

After a 5-day storage of the whey protein treatment at $4{ }^{\circ} \mathrm{C}$, number of $K$. pneumoniae cells reached $4.67 \times 10^{5}$ $\mathrm{CFU} / \mathrm{g}$ and recorded a $2.2 \%$ decrease, compared to control. On Day 10, the mean number of $K$. pneumoniae in the whey protein treatment decreased by $8.32 \%$, compared to control and the number of live bacteria reached $4.38 \times 10^{5}$ $\mathrm{CFU} / \mathrm{g}$. This reached $4.28 \times 10^{5} \mathrm{CFU} / \mathrm{g}$ on Day 15 , which showed a decrease of $10.4 \%$ (Fig. 3 ).

\section{Disk diffusion experiments}

Mean diameters of the inhibition zones of E. coli, Enterobacter and $K$. pneumoniae using only whey protein coating with no essential oil (treatment no. 4) were reported as $5.24,3.01$ and $2.14 \mathrm{~mm}$, respectively. Using $0.5 \%$ of the essential oil could cause increases of $98.85 \%$ in E. coli inhibition zone. A $153.82 \%$ increase in the inhibition zone was recorded for Enterobacter, using $0.5 \%$ essential oil with whey protein coating. For $K$. Pneumoniae, no enhancement was seen when $0.5 \%$ of the essential oil was used in the antibacterial coating system (Table 1). At the concentration of $1 \%$ essential oil, values increased by 152.48, 245.18 and $65.42 \%$ for E. coli, Enterobacter and $K$. pneumoniae, respectively. Using essential oil at a concentration of $1.5 \%$, maximum mean diameters of the inhibition zones were achieved and 261.07, 261.46 and $68.22 \%$ increases were respectively reported for $E$. coli, Enterobacter and $K$. pneumoniae, compare to control (Table 1).

\section{Organoleptic and sensory characteristics of the treatments}

As data show in Table 2, 85\% of acceptance were achieved for taste and odor and $100 \%$ of acceptance for appearance and color of the products. 
Sajedeh Rezaiee, et al: Antibacterial properties of whey protein coating and mentha aquatica L. essence

Table 1. Mean diameters of the inhibition zones of Escherichia coli PTCC1330 (O157:H7), Enterobacter PTCC1291 and Klebsiella pneumoniae PTCC1290 using various Mentha aquatica L. essential oil doses and whey protein coating

\begin{tabular}{cccc}
\hline Treatment Number & $\begin{array}{c}\text { Mean diameter of the } \\
\text { inhibition zone for } E . \\
\text { coli }(\mathrm{mm})\end{array}$ & $\begin{array}{c}\text { Mean diameter of the } \\
\text { inhibition zone for } \\
\text { Enterobacter }(\mathrm{mm})\end{array}$ & $\begin{array}{c}\text { Mean diameter of the } \\
\text { inhibition zone for } K . \\
\text { pneumoniae }(\mathrm{mm})\end{array}$ \\
\hline 1 & $10.42 \pm 0.43$ & $7.64 \pm 0.27$ & $2.06 \pm 0.13$ \\
2 & $13.23 \pm 0.06$ & $10.39 \pm 0.12$ & $3.54 \pm 0.08$ \\
3 & $18.92 \pm 0.04$ & $10.88 \pm 0.71$ & $3.60 \pm 0.33$ \\
4 & $5.24 \pm 0.65$ & $3.01 \pm 0.18$ & $2.14 \pm 0.20$ \\
5 & 0 & 0 & 0 \\
\hline
\end{tabular}

Table 2. Organoleptic assays of the Iranian white cheese containing 1.5\% of Mentha aquatica L. essential oil

\begin{tabular}{ccccc}
\hline Organoleptic factor & $\begin{array}{c}\text { Positive comments No. } \\
\text { (from 40 tester) }\end{array}$ & $\begin{array}{c}\text { Positive comments } \\
(\%)\end{array}$ & $\begin{array}{c}\text { Negative comments No. } \\
\text { (from 40 tester) }\end{array}$ & $\begin{array}{c}\text { Negative comments } \\
(\%)\end{array}$ \\
\hline Taste & 34 & $85 \%$ & 6 & $15 \%$ \\
Odor & 34 & $85 \%$ & 6 & $15 \%$ \\
Color & 40 & $100 \%$ & 0 & 0 \\
Appearance & 40 & $100 \%$ & 0 & 0 \\
\hline
\end{tabular}

\section{Discussion}

For MIC and MBC of E. coli, Carvalho et al. (2018) reported MIC of $0.39 \%$ for pepper mint essential oil against E. coli ATCC25922 (24). In the present study, 0.2\% essential oil dose was reported as MIC value. Based on the achieved values of MIC and MBC for the bacterial strains, concentrations of $0.5,1$ and $1.5 \%$ of $M$. aquatica L. essential oil were considered for the antibacterial assessment in this study. Due to the numerous reports on cheese contamination with $E$. coli, effects of $M$. aquatica L. essential oil on the bacteria from the Iranian white cheese were studied in the present study. Hygiene of the foods in terms of their microbial load and shelf-life depends on the decrease of the primary food contamination and preventing or limiting growth of the bacterial population. Based on the results, M. aquatica L. essential oil showed acceptable antibacterial effects at various doses. In treatment of $1.5 \% \mathrm{M}$. aquatica L. essential oil, growth of E. coli was almost stopped completely on Day 15 . In whey protein treatment, the mean number of $E$. coli cells decreased by $8 \%$ after five days of storage at $4{ }^{\circ} \mathrm{C}$, compared to control. Moreover, number of the bacteria reached $5.15 \times 10^{5} \mathrm{CFU} / \mathrm{g}$. On Day 10 , the mean number of E. coli in whey protein treatment decreased by $19.1 \%$, compared to control. Furthermore, number of the live bacteria reached $4.53 \times 10^{5} \mathrm{CFU} / \mathrm{g}$. This reached $3.47 \times 10^{5}$ CFU/g on Day 15, which showed a decrease of $38 \%$ (Fig. 1). The major reason for increases in number of the bacteria in control sample after five days was linked to growth and proliferation of the bacteria in cheese samples and process of the bacterial logarithmic growth. After five days, number of the live bacteria gradually decreased, which was a natural phenomenon in bacterial cell population. The most important reason could be linked to changes in the cheese $\mathrm{pH}$.
Based on the results, use of $0.5 \% M$. aquatica L. essential oil with whey protein coating could inhibit $E$. coli growth in Iranian white cheese by up to $60 \%$ after 15 days of storage at $4{ }^{\circ} \mathrm{C}$. However, only up to $38 \%$ of the bacterial growth were inhibited during this time using whey protein coating with no $M$. aquatica L. essential oil. In control sample (with no whey protein coating or $M$. aquatica L. essential oil), inhibition of $E$. coli growth after 15 days of storage at $4{ }^{\circ} \mathrm{C}$ was normally seen up to $14 \%$. Therefore, it can be concluded that the presence of whey protein coating and $M$. aquatica L. essential oil included significant antibacterial effects against E. coli PTCC1330 (O157:H7) in Iranian white cheese. By increasing the concentration of $M$. aquatica L. essential oil from 0.5 to $1.5 \%$, inhibition rate of the bacterial growth increased significantly. As the concentration of essential oil increased from 0.5 to $1 \%$, inhibition rate of the bacterial growth increased from 59 to $75 \%$. With the increase of essential oil concentration from 1 to $1.5 \%$, inhibition rate of the bacterial growth increased from 75 to $98 \%$. At $1.5 \%$ of the essential oil, growth of $E$. coli was completely inhibited. Antibacterial properties of $\alpha$-pinene, one of the most important chemicals of M. aquatica L., against $E$. coli have been reported by the researches (25). Karim and Bonyadian (2004) studied antimicrobial effects of volatile oils of thyme (Thmus Vulgaris), tarragon (Arlemisia dracunculus), caraway seed (Caram Carvi), penny royal (M. pulgium) and peppermint (M. piperita) on E. coli in Iranian white cheese (26). They reported that thyme included the highest antimicrobial effects on $E$. coli. After seven days of incubation with 0.3 and $0.4 \%$ concentrations of $M$. piperita essential oil, 40 and $46 \%$ decreases were respectively achieved in E. coli cell number; similar to those achieved in the present study. Moreover, significant antibacterial effects of $M$. aquatica L. extract (27) and M. piperita L. essential oil (28) on $E$. coli were reported. 
Results of culturing and counting live Enterobacter PTCC1291 in various treatments showed that use of whey protein coating with $M$. piperita essential oil in various doses included antibacterial effects in inhibiting growth of the coliformic bacteria such as E. coli. In treatment of $1.5 \%$ M. piperita essential oil on Day 15, growth of Enterobacter was inhibited by $64 \%$. Results showed no significant differences between the concentrations of 1 and $1.5 \%$ of $M$. piperita essential oil in inhibiting growth of Enterobacter on Days 5, 10 and 15. Moreover, no significant differences were observed in effects of storage time on decreasing number of live bacteria between Days 10 and 15 in each of the essential oil doses. In general, it could be concluded that the antibacterial effect of $M$. piperita essential oil against Enterobacter PTCC1291 was much less than that against E. coli. The initial live cells of Enterobacter in control increased after five days. However it decreased at the end of the storage time (Day 15) by almost 9\%, compared to Day 1 (Fig. 2). The reason of this was quite similar to that of E. coli.

Results of this study indicated that Enterobacter PTCC1291 was more resistant than E. coli PTCC1330 (O157:H7). Results of this section showed that an inhibition factor of $44 \%$ could be achieved for Enterobacter proliferation rate after 15 days of storage at 4 ${ }^{\circ} \mathrm{C}$ using $0.5 \%$ of $M$. aquatica essential oil with whey protein coating. Without the presence of $M$. aquatica essential oil and by use of whey protein alone, growth of the bacteria was inhibited up to $31 \%$. Antibacterial effects of $M$. aquatica essential oil and whey protein coating were milder for Enterobacter than E. coli. In control samples, inhibition of the bacterial growth was naturally observed up to $9 \%$ after 15 days of storage at $4{ }^{\circ} \mathrm{C}$. Therefore, it could be concluded that the presence of whey protein coating included significant effects on inhibition of Enterobacter growth in Iranian white cheese. However, effects of $M$. aquatica essential oil at $0.5 \%$ on inhibiting the growth of these bacteria were not significant. With increases in concentration of the essential oil from 0.5 to $1 \%$, inhibition rate of the bacterial growth increased significantly from 44 to $61 \%$. However, increasing concentration of the essential oil from 1 to $1.5 \%$ did not include significant effects on increasing antibacterial properties of the essential oil. The essential oil ability to inhibit the bacterial growth increased by only $3 \%$ from 61 to $64 \%$. Use of whey protein and $M$. aquatica essential oil up to $60 \%$ could inhibit growth of Enterobacter in cheese samples. Although antibacterial effects of the whey protein and M. aquatica essential oil on Enterobacter were not as significant as their effects on $E$. coli, comparing growth inhibition of Enterobacter in control (no whey protein coating and essential oil) with the coated sample with $5 \%$ of the essential oil, use of whey protein coating and $1.5 \%$ of essential oil inhibited growth of Enterobacter in cheese samples by nearly seven times.
The bridged bi-cyclic monoterpenes such as $\alpha$-pinene and $\beta$-pinene as two important ingredients of $M$. aquatica essential oil included significant antibacterial activities (29). Studies by Ferhat et al. (2017) showed considerable antibacterial properties of $M$. aquatica L. extract on $E$. aerogenes (27).

Studies on the effects of various doses of $M$. aquatica essential oil with whey protein coating on $K$. pneumoniae growth inhibition indicated that the designed antibacterial system included a little antibacterial effects against the bacteria. In principle, $K$. pneumoniae is one of the most resistant bacteria that are resistant to several antibiotics (30). Results of this study showed that $M$. aquatica essential oil could not inhibit growth of the bacteria in cheese samples to acceptable levels. Based on the results of storage at $4{ }^{\circ} \mathrm{C}$ on Day 5 , viable cells of $K$. pneumoniae decreased as 2.93, 8.99 and $9.8 \%$ and reached $4.64 \times 10^{5}$, $4.35 \times 10^{5}$ and $4.31 \times 10^{5} \mathrm{CFU} / \mathrm{g}$ respectively in treatments of $0.5,1$ and $1.5 \%$ essential oil, compared to control. After 10 days of storage at $4{ }^{\circ} \mathrm{C}$, decreases of $8.99,14.4$ and $15.9 \%$ were recorded for the treatments of $0.5,1$ and $1.5 \%$ essential oil, respectively. Moreover, number of $K$. pneumoniae cells reached $4.35 \times 10^{5}, 4.09 \times 10^{5}$ and $4.02 \times$ $10^{5} \mathrm{CFU} / \mathrm{g}$, respectively in treatments of $0.5,1$ and $1.5 \%$ essential oil. After 15 days storage at $4{ }^{\circ} \mathrm{C}$, number of $K$. pneumoniae decreased as $11.2,17.57$ and $18.41 \%$ and reached $4.24 \times 10^{5}, 3.94 \times 10^{5}$ and $3.90 \times 10^{5} \mathrm{CFU} / \mathrm{g}$ respectively in treatments of $0.5,1$ and $1.5 \%$ essential oil, compared to control (Fig. 3).

In various treatments with various doses of $M$. aquatica L. essential oil and whey protein coating, no significant differences were seen in number of live $K$. pneumoniae and its inhibition growth rate. These results suggested that use of whey protein and M. aquatica L. essential oil did not include significant effects on growth inhibition of $K$. pneumoniae. In fact, it seems that the presence of whey protein coating and various concentrations of $M$. aquatica L. essential oil mildly accelerated decreases in number of live bacteria in consecutive days of storage, compared to decreases in number of live bacteria in control. Furthermore, a small decreases were reported in number of live cells of $K$. pneumoniae at the end of Day 15 of incubation. At the concentrations of 1 and $1.5 \%$ essential oil, decreases in number of live bacteria respectively were 17.57 and $18.41 \%$ after 15 days, which were almost twice the decreases of live bacteria in control. Therefore, results of the experiments in this section demonstrated that whey protein coating and $M$. aquatica L. essential oil were not good options for inhibiting growth of $K$. pneumoniae in Iranian white cheese. A review of results achieved in this section revealed that using a concentration of $0.5 \%$ essential oil with whey protein coating resulted in only $11 \%$ inhibition of the bacterial growth in cheese samples after 15 days of incubation at $4{ }^{\circ} \mathrm{C}$. However, if essential 
oil was not used and only whey protein coating was used, the bacterial growth was inhibited up to $10.4 \%$. Presence of $0.5 \%$ essential oil did not include overall antibacterial effects on the bacteria. Since inhibition of the bacterial growth in control (with no coating and essential oil) was nearly $10 \%$ after 15 days of storage at $4^{\circ} \mathrm{C}$ (natural inhibition), it could be concluded that use of whey protein coating included no effects on the bacterial growth inhibition. By increasing concentration of the essential oil from 0.5 to 1 and $1.5 \%$, inhibition rate of the bacterial growth did not increase significantly, reaching from 11 to $18 \%$. Comparison of the bacterial growth inhibition of $K$. pneumoniae in control with whey protein coated sample and $1.5 \%$ of the essential oil indicated that use of these techniques caused only a two-time inhibition in the bacterial growth. However, other researchers reported good antibacterial properties of M. aquatica L. extract (27) and M. piperita L. essential oil (28) on K. pneumonia.

Antibacterial effects of essential oil extracted from $M$. aquatica L. leaves with biopolymer coating of whey protein on E. coli PTCC1330 (O157:H7), Enterobacter PTCC1291 and K. pneumoniae PTCC1290 were studied using disk diffusion method. The inhibition zone diameters demonstrated that $M$. aquatica $\mathrm{L}$. essential oil negatively affected all the three bacterial strains at all concentrations. The $K$. pneumoniae was reported as the most resistant strain against doses of the essential oil with growth on the culture media. The $M$. aquatica L. essential oil at a concentration of $1.5 \%$ was able to inhibit growth of E. coli on surface of the culture media. The M. aquatica L. essential oil showed a good antibacterial ability to decrease cheese contamination loads of E. coli and Enterobacter. For K. pneumoniae, antibacterial effects of M. aquatica L. essential oil on inhibition of the bacterial species were not significant. These results verified results from the previous section (culturing and counting bacteria in various treatments). These data showed that $M$. aquatica $\mathrm{L}$. essential oil included significant antibacterial effects on $E$. coli. However, Enterobacter was more resistant to the antibacterial effects of this essential oil than that $E$. coli was. Antibacterial effects of $M$. aquatica L. essential oil on $K$. pneumoniae were not significant.

Ingredient analysis of $M$. aquatica L. essential oil using mass spectrometry showed that the major effective ingredients of this essential oil included $78.8 \%$ of carvone (methyl-5-(1-methylethenyl)-2-cyclohexenone), 11.5\% of limonene (dioxo-716-dideoxylimondiol-716), $1.43 \%$ of dihydrocarveol (2-methyl-5-prop-1-en-2-ylcyclohexan-1ol), $1.23 \%$ of $\beta$-bourbonene ( $(1 S, 2 R, 6 S, 7 R, 8 S)$-1-methyl-5methylidene-8-propan-2-yltricyclo[5.3.0.0 $\left.0^{2,6}\right]$ decane),

$1.04 \%$ of trans-caryophyllene (4,11,11-trimethyl-8methylidenebicyclo[7.2.0]undec-4-ene), $1 \%$ of menthone (2-isopropyl-5-methylcyclohexanone-2S5R) and $1 \%$ of terpinene (4-methyl-1-(1-methylethyl)-1,3-cyclohexadiene) with no special odor, color or taste (31). Bayan and Kusek (2018) reported $11.63 \%$ of limonene, $56.94 \%$ of carvone, $4.06 \%$ of caryophyllene, $3.4 \%$ of dihydrocarvone, $2.49 \%$ of terpinene and $1.93 \%$ of $\beta$-bourbonene in M. spicata $\mathrm{L}$. volatile oil (32). Silveira et al. (2012) reported $86.05 \%$ of menthol and $3.44 \%$ of menthone for $M$. arvensis $\mathrm{L}$. essential oil and $25.67 \%$ of $\beta$-caryophyllene, $12.55 \%$ of germacrene D, $\% 9.37$ of menthol, $6.86 \%$ of germacrene B and $5.61 \%$ of menthone for M. pulegium, L. which revealed significant differences in the essential oil compositions depending on Mentha varieties and cultivation regions (33). After carrying out organoleptic assessments, smell, color, taste and appearance of $M$. aquatica L. essential oil were reported popular, based on the Iranian taste.

\section{Conclusion}

Results of this study showed that use of M. aquatica L. essential oil with whey protein coating significantly decreased number of the highlighted bacteria in treatment groups and in groups including whey protein coating alone. Antibacterial effects of $M$. aquatica L. essential oil on growth inhibition of the bacteria showed that whey protein coating with $M$. aquatica L. essential oil was able to inhibit growth of E. coli and Enterobacter in Iranian white cheese and could play roles of a natural preservative in controlling these bacteria. Using $1.5 \%$ of the essential oil in Iranian white cheese, cheese could be provided to the market after the end of Day 15 of storage at $4^{\circ} \mathrm{C}$. Although smell of $M$. aquatica $\mathrm{L}$. in cheese with $1.5 \%$ of essential oil was mildly felt; however, it seemed that this type of cheese included an acceptable taste for the Iranian consumers. The optimal concentration of $M$. aquatica L. essential oil was estimated to achieve the highest inhibitory growth rates of $E$. coli, Enterobacter and K. pneumoniae, preserving organoleptic and sensory properties of the cheese. In all treatments, approximately 1 and $1.5 \%$ concentrations of the essential oil included more antibacterial effects than that $0.5 \%$ concentration of the essential oil did. For E. coli, antibacterial effects of $1.5 \%$ of the essential oil were significantly higher than those of $1 \%$ of the essential oil. Therefore, $1.5 \%$ concentration of the essential oil was considered as the optimal concentration to inhibit growth of E. coli in cheese samples. No significant differences were seen between the antibacterial effects of $M$. aquatica L. essential oil at 1 and $1.5 \%$ concentrations on Enterobacter and K. pneumoniae. For Enterobacter and K. pneumoniae, $1 \%$ concentration of the essential oil was reported as the optimal dose of the essential oil. In conclusion, this essential oil can be used in Iranian white cheese and the essential oil extracted from the leaves of this plant can be suggested to use in dairy industries as an alternative, natural safe preservative. 


\section{Acknowledgement}

The authors wish to thank Offices of Vice Chancellor for Research of the Islamic Azad University, Qaemshahr and Shahrood Branches, for their experimental and analytical assistances in this study.

\section{Financial disclosure}

The authors declare no personal or financial conflicts.

\section{Authors' contributions}

The present study was resulted from S. R.'s master thesis. S. R. and F. A. contributed to experimental investigations and data collection. M. K. prepared necessary facilities for the experiments. F. A. contributed to the study as supervisor and M. K. as advisor. F. A. prepared the manuscript draft and all authors approved the final version of the manuscript.

\section{References}

1. Huang T, Qian Y, Wei J, Zhou C. Polymeric antimicrobial food packaging and its applications. Polymers 2019; 11(3): 560-77.

2. Irkin R, Esmer OK. Novel food packaging systems with natural antimicrobial agents. J Food Sci Technol 2015; 52(10): 6095111

3. Vergis J, Gokulakrishnan P, Agarwal RK, Kumar A. Essential oils as natural food antimicrobial agents: a review. Crit Rev Food Sci Nut 2015; 55(10): 1320-23.

4. Seydim AC, Sarikus G. Antimicrobial activity of whey protein based edible films incorporated with oregano, rosemary and garlic essential oils. Food Res Int 2007; 39(5): $639-44$

5. Tokur BK, Sert F, Aksun ET, Ozogul F. The effect of whey protein isolate coating enriched with thyme essential oils on trout quality at refrigerated storage $\left(4 \pm 2^{\circ} \mathrm{C}\right)$. J Aqua Food Pro Technol 2016; 25(4): 585-96.

6. Moosavi MH, Esmaeili S, Mostafavi S. Antibacterial effect of Mentha spicata essential oil on Listeria monocytogenes in traditional lighvan cheese. J Food Safety 2013; 33(4): 509-14.

7. H T Zavareh SA, Ardestani F. Antibacterial effects of chitosan coating containing Mentha aquatica L. essence against Escherichia coli, Staphylococcus aureus and Listeria monocytogenes in Iranian white cheese. Int J Dairy Technol 2020; 73(3): 585-93.

8. Beigmohammadi F, Peighambardoust SH, Hesari J, Peighambardoust SJ. Inhibition of Coliform bacteria in ultrafiltered cheese packed in nanocomposite films containing cloisite30B metal nanoparticles. Nutr Food Sci Res 2018; 5(1): 23-30.

9. Marcous A, Rasouli S, Ardestani F. Low-density polyethylene films loaded by titanium dioxide and zinc oxide nanoparticles as a new active packaging system against Escherichia coli O157:H7 in fresh calf minced meat. Pack Technol Sci 2017, a; 30: 693-701.

10. Marcous A, Rasouli S, Ardestani F. Inhibition of Staphylococcus aureus growth in fresh calf minced meat using low density polyethylene films package promoted by titanium dioxide and zinc oxide nanoparticles. J Particle Sci Technol 2017, b; 3: 1-11.

11. Khorasany S, Azizi MH, Barzegar M, Hamidi Esfahani Z. A study on the chemical composition and antifungal activity of essential oil from Thymus caramanicus, Thymus daenensis and Ziziphora clinopodiaides. Nutr Food Sci Res 2016; 3(2): $35-42$.

12. Ramezanpour S, Ardestani F, Asadollahzadeh MJ. Combination effects of Zataria multiflora, Laurus nobilis and Chamaemelum nobile essences on pathogenic E. coli and determination of optimum formulation using fraction and factorial statistical method. Iranian J Med Microbiol 2016; 10(2): 56-65.

13. Tong SY, Lim PN, Wang K, Thian ES. Development of a functional biodegradable composite with antibacterial properties. J Materials Technol 2018; 33(11): 754-59.

14. Joyande H, Koravand F. The influence of enzymatic treatment time of microbial transglutaminase on the properties of edible film based on whey protein isolate. Iranian J Biosys Eng 2016; 47(3): 519-27.

15. Perez-Gago MB, Krochta JM. Denaturation time and temperature effects on solubility, tensile properties and oxygen permeability of whey protein edible films. J Food Sci 2001; 66(5): 705-10.

16. Azhdarzadeh F, Hojjati M. Chemical composition and antimicrobial activity of life, ripe and unripe peel of bitter orange (Citrus aurantium) essential oils. Nutr Food Sci Res 2016; 3(1): 43-50.

17. Clements A, Young JC, Constantinou N, Frankel G. Infection strategies of enteric pathogenic Escherichia coli. Gut Microbes 2012; 3(2): 71-87.

18. Martin RM, Bachman MA. Colonization, infection and the accessory genome of Klebsiella pneumonia. Frontiers Cellular Infection Microbiol 2018; 8(4): 1-15.

19. Jha P, Kim CM, Kim DM, Chung JH, Yoon NR, Jha B, Kim S W, Jang SJ, Ahn YJ, Chung JK, Jeon DY. Transmission of Enterobacter aerogenes septicemia in healthcare workers. Springerplus 2016; 5(1): 1397-1400.

20. Tavakolipour H, Kalbasi-Ashtari A, Mokhtarian M. Effects of coating pistachio kernels with mixtures of whey protein and selected herbal plant extracts on growth inhibition of Aspergillus flavus and prevention of aflatoxin during storage. J Food Safety 2020; 40(1): 12711.

21. Riazi F, Zeynali F, Hoseini E, Behmadi H. Determination of the minimum inhibitory concentration of the Barberry extract and the dried residue of red grape and their effects on the growth inhibition of sausage bacteria by using response surface methodology (RSM) . Nutr Food Sci Res 2015; 2(4): 55-63.

22. McFarland JMD. The nephelometer: an instrument for estimating the number of bacteria in suspensions used for calculating the opsonic index and for vaccines. J American Med Associat 1907; 14: 1176-8.

23. A Khan Z, F Siddiqui M, Park S. Current and emerging methods of antibiotic susceptibility testing. Diagnostics (Basel) 2019; 9(2): 49.

24. Carvalho M, Albano H, Teixeira P. In vitro antimicrobial activities of various essential oils against pathogenic and spoilage microorganisms. J Food Quality Hazards Control 2018; 5, 41-8. 
25. Hajlaoui H, Terabelsi N, Noumi E, Snoussi M, Fallah H, Ksouri R, Bakhrouf S. Biological activities of the essential oils and methanol extract of two cultivated Mint species (Mentha longifolia and Mentha pulegium) used in the Tunisian folkloric medicine. World J Microbiol Biotechnol 2009; 25: 2227-38.

26. Karim G, Bonyadian M. Study on the antimicrobial effect of the volatile oils of some herbs on E.coli in Iranian white cheese. Iranian J Food Sci Technol 2004; 1(1): 21-8.

27. Ferhat M, Erol E, Beladjila KA, Cetintas Y, Duru ME, Ozturk M, Kabouche A, Kabouche Z. Antioxidant, anticholinesterase and antibacterial activities of Stachys guyoniana and Mentha aquatic. Pharm Biology 2017; 55(1): 324-9.

28. Muntean D, Licker M, Alexa E, Popescu I, Jianu C, Buda V, Dehelean CA, Ghiulai R, Horhat F, Horhat D, Danciu C. Evaluation of essential oil obtained from Mentha piperita $\mathrm{L}$. against multidrug-resistant strains. Infection Drug Resist 2019; 12: 2905-14.
29. Stoyanova A, Georgie V, Kula J, Majda T. Chemical composition of the essential oil of Mentha pulegium from Bulgaria. J Essential Oil Res 2005; 17: 475-7.

30. Garbati MA, Godhair AIA. The growing resistance of Klebsiella pneumoniae; the need to expand our antibiogram: case report and review of the literature. African J Infectious disease $2013 ; 7(1): 8-10$

31. Morteza-Semnani K, Saeedi M, Akbarzadeh_ M. The essential oil composition of Mentha aquatica L. J Essential Oil Bearing Plants 2006; 9(3): 283-6.

32. Bayan Y, Kusek M. Chemical composition and antifungal and antibacterial activity of Mentha spicata $\mathrm{L}$. volatile oil. Ciencia e Invest Agraria 2018; 45(1): 64-9.

33. Silveira SM, Junior AC, Scheuermann GN, Secchi FL, Vieira CRW. Chemical composition and antimicrobial activity of essential oils from selected herbs cultivated in the South of Brazil against food spoilage and foodborne pathogens. Ciencia Rural 2012; 42(7): 1300-6. 